\title{
Entrepreneurship and Employment Adaptability Concept Teaching
}

\author{
TianYi Qu ${ }^{1, a}$ and Kui Chen ${ }^{2, b}$ \\ ${ }^{1}$ School of Management, XuZhou institute of Technology, Xuzhou, Jiangsu, China 221008 \\ ${ }^{2}$ China University of Mining \& Technology, Xuzhou, Jiangsu, China 221008 \\ ajdbh2001@163.com bckbhxtlc73@sina.com
}

\begin{abstract}
Keywords: Entrepreneurship; Employment adaptability; Teaching system; Teaching philosophy; Exploration
\end{abstract}

\begin{abstract}
At present, although our country gives priority to college graduates with supporting policies; it has not solved the problems of graduate employment and entrepreneurship. This paper analyzes these problems of graduate entrepreneurship, employment and vocational adaptability; and offers suggestions and methods to solve them from different aspects, so that it can improve the graduates' entrepreneurship, employment and vocational adaptability.
\end{abstract}

\section{Introduction}

Nowadays employment and entrepreneurship have been the biggest problems faced by college graduates. Although our country gives priority to college graduates with supporting policies, it has not solved the problems of graduate employment and entrepreneurship, which has something to do with the market environment, the economic development mode and ways of education. What's more, the situation is close to the cultivation and development of college students' entrepreneurship and vocational adaptability at an early time. A survey on graduate entrepreneurship, employment and vocational adaptability shows that under same conditions, the more thorough the university's concept of cultivating its students' entrepreneurship, employment and vocational adaptability is, the earlier its students start their plans on entrepreneurship, employment and vocational adaptability, the stronger its students' entrepreneurship, employment and vocational adaptability is, the more capable its students are, and the greater achievements its students tend to make.

Therefore, in order to enhance the college students' entrepreneurship, employment and vocational adaptability, this paper studies how to help students establish the concept of entrepreneurship, employment and vocational adaptability in daily teaching early and cultivate their tailor-made concept so as to improve their entrepreneurship, employment and vocational a

\section{Current Problems Regarding College Students' Entrepreneurship Employment and Vocational Adaptability}

Inadequate understanding of entrepreneurship education

Since our country's higher education focuses on academic qualifications, the entrepreneurship education started very late. With inadequate study and understanding, the entrepreneurship education is not paid enough attention to. The reasons why entrepreneurship education belongs to mainstream education are demonstrated in the following four aspects: firstly, the concept of entrepreneurship is vague. The lack of a clear definition of the entrepreneurship qualifications makes the realization of entrepreneurship education impossible. Secondly, it is believed that entrepreneurship education only includes incentives. That is to say, mere entrepreneurship lectures are given to encourage college students to start their businesses after graduation. Thirdly, entrepreneurship education just concentrates on entrepreneurial skills with the cultivation and development of entrepreneurship concept and consciousness ignored. Fourthly, it seems that entrepreneurship education can train outstanding students in a short term. Without a set of comprehensive systems or modes, it is not feasible to realize entrepreneurship in a short period.

Curriculum setting is relatively backward 
Now, most enterprises and institutions in our country take qualifications and knowledge as the first standard when they are recruit talent. This causes Colleges and universities attach great importance to the theoretical curriculum, discipline-centered and the knowledge system. They often focus on teaching subject knowledge, set up different curriculum based on different flied. neglecting to cultivate students' practice ability. Colleges and universities has never thought about it, whether these subjects make really contribution to cultivating students' employ ability and entrepreneurial ability. Furthermore, China's colleges and universities did not establish entrepreneurial talent training objectives for a long time, Which leads to the curriculum setting and training of entrepreneurial talent is not adapt to entrepreneurship theory and practice courses are not enough. At present China's colleges and universities only created some business intensive courses, lectures and training, and in the present curriculum relates to employment and entrepreneurship education content is less, this kinds of curriculum cannot meet the demand for knowledge and practice of entrepreneurship and employment situation.

Single teaching method

There is a great difference between the teaching method and the traditional teaching method to cultivate the entrepreneurial talents. If we use traditional teaching methods, we will restrict the cultivation of entrepreneurial talents. Due to the influence of curriculum and teachers ' professionalism, the explanation of theory course often based on language, teacher-centred teaching methods, this single teaching-oriented teaching methods, make classroom lack of interaction, blindly focusing on knowledge infusion.

School enterprise cooperation is not ideal

As an important participant in the social economy, enterprises have great influence on the cultivation of entrepreneurial talents. University and enterprise cooperation is one of the important ways to cultivate entrepreneurial talent. However, there are many problems existing in the university and enterprise cooperation, for example, the university is less active and the enterprise union, the enterprise participates in the enterprise personnel training the enthusiasm is not high. The current school enterprise cooperation, colleges and universities and enterprises do not really allow students to participate in the production practice of the enterprise, just repeat the simple labor. This kinds of cooperation does not play the role of cultivating students' entrepreneurial ability, an obstacle to the improvement of students' pioneering accomplishment.

\section{Methods of Improving Students' Entrepreneurship, Employment and Career Adaptability}

Set up special entrepreneurship, employment and career planning courses

Entrepreneurship Education in Colleges and universities is not only an independent system, but also combined with the professional education and complement each other closely through the professional teaching system. The talent training program is study principle in four years, it reflect educational thought and training direction of university. Embedding entrepreneurship education courses in the talent training program can grasp the development of entrepreneurship education from the source. We can draw on the experience from entrepreneurship curriculum design of famous Business School. The independence of entrepreneurship courses can be applied to different subjects in different disciplines. Combined with the actual situation of our country's Higher Education, establish a system of saturated enterprise education. Namely in the professional learning at the same time to supplement the entrepreneurial knowledge, understanding the basic skills of the enterprise founded, management and operation, more in line with the current stage of student awareness and social needs. After the completion of the basic knowledge of entrepreneurship, college students can also carry out through the practice of the University and business operations. Through the practice to master more business opportunities, business growth and financial accounting knowledge, which is of great help to improve the success rate of entrepreneurship.

In order to improve the student's employment and entrepreneurship, Some colleges and universities set up special entrepreneurship, employment and career planning courses, cultivating students' employment, entrepreneurship and career planning ability, laying the foundation for future employment and work. The method has a certain help, but has great limitations. 
Construction of professional practice teaching system and organization

Professional practice teaching is the basis for the students to carry on the post simulation operation, and it is the guarantee of the ability of the students to start a business. The construction of practical teaching system should be based on the basic ability training, with comprehensive quality training as the core, with the spirit of education as the main line. Perfect the "basic skills training - a professional skill training - a production practice training - a science and technology training" four levels of integration, open, strong application of the practical teaching system.

In the professional practice teaching system, the entrepreneurial ability is the highest level and ultimate goal of the training. To program the time as a clue, through professional practice teaching four levels, students can grasp the professional practice skills. At the same time through the entrepreneurial training, to master a wealth of entrepreneurial knowledge. Finally, through the practice of teaching and training, to master the professional ability and entrepreneurial ability.

Reform of standard system for examination and assessment of entrepreneurship

The inspection result is a focus of attention of students, which plays an important guiding role in students' learning methods and learning content. Entrepreneurship education in colleges and universities can not only stay in the aspect of spirit to encourage, and be more concerned about the issue of the students. Building standards for examination and assessment of entrepreneurship in the student assessment system, can guide students to autonomous learning, and improve the students' ability of independent thinking and solving problems, so the students can for entrepreneurial learning practice can learn business practices actively without any concern.

Venture evaluation standard reform must focus on scientific comprehensive evaluation of students' comprehensive quality, strengthening practical ability, application ability and the ability of the inspection. We should get "Pay attention to the assessment of students' practical ability", "comprehensive assessment", "process evaluation" and other advanced concept into the curriculum evaluation method in the reform, and establish a two-way type, communication type evaluation information feedback mechanism to get the function of improving teaching and research method to be implemented. On the results of quantitative evaluation, supplement and complete business factors should be perfected; In the evaluation of moral education, entrepreneurial awareness standards should be added; In the intellectual education assessment, entrepreneurial capability assessment should be included. Through reform, we can build a set of accord with the characteristics of entrepreneurial talent training requirements and the professional examination evaluation system.

Optimizing the organizational structure of entrepreneurship education

Running smoothly, scientific and rational organization structure is the guarantee of the sustainable development of the enterprise education in Colleges and Universities. In the University Entrepreneurship organization structure should follow the principle of single center, multi-level, wide coverage. At the school level, the universities should be established with the market convergence of the market or business management center, responsible for external contact and internal communication, to guide the school's entrepreneurship education. At the department level, establish of the business office, which is the same level with the Department of teaching work office, the student work office. At the student level, all grates will set up a business practice association. At the teacher level, the establishment of entrepreneurship education development center, which is responsible for the school double teachers and part-time teachers, specially the enterprise instructors of social teachers management.

To establish university-enterprise cooperation practice bases

Practice is the important way to cultivate innovative and entrepreneurial talents. Enterprises are the important participant to cultivate innovative and entrepreneurial talents. Colleges and universities should joint enterprises, and go the way of university-enterprise cooperation, which has complementary advantages and resource sharing, together to create entrepreneurial innovation practice base, and practice platform. Fist, colleges and universities communicate actively with the enterprises to build cooperative relationship. University-enterprise cooperation can let students walk into the field of the production practice, to understand the management and operation of enterprises. 
It stimulates students' entrepreneurial enthusiasm, and improves their business ability, and cultivates their innovation consciousness in the practice of the enterprise.

Second, enterprises should have long-term view to treat the innovation as an significant question in the enterprise development. They should actively participate in the university's entrepreneurial talent training work. On the one hand, they actively express their talent requirements to university, and introduce entrepreneurial innovation talent. On the other hand, provide practical chance for students, and offer practical guide of management, decision, risk and investment. Adults can get real exercise and satisfy their leaning needs from these.

Entrepreneurial innovation talents are cultivated by universities and enterprises which strength is not enough. Because the cultivation is a complicated, systemic project. The government will introduce a series of relevant policies, in order to offer external support and assurance to the cultivation of Entrepreneurial innovation talents.

First, building cultural environment of entrepreneurial innovation. The government is the impeller and facilitator of entrepreneurial innovation education in colleges and universities, so, it will introduce a series of relevant policies to encourage colleges and universities to cultivate entrepreneurial innovation talents, and build a nice, relaxed, fair environment for it.

Second, providing financial security. The government should increase financial investment though setting up a special found of entrepreneurial innovation talents, offering business-setup loans, and so on. Stepping up contributions of entrepreneurial innovation talents and teams maximally guarantee their expenditure autonomy, to make up for the problems such as insufficient funds, and try their best to solve difficulties in terms of money.

Third, offering policy guarantee measures. Government should establish and improve the family, medical insurance and other aspects of the service supporting policies. Government should establish and perfect the family, medical insurance and other aspects of services supporting policies, encourage the development of preferential policies for innovation and entrepreneurship, provide convenient in industrial and commercial registration and office space, provide security services for the innovative entrepreneurial talent, solve their worries.

\section{Conclusion}

Carrying out innovation and entrepreneurship education activities can mobilize students' subjective initiative, stimulate students' potential, and help to improve students' self-accomplishment. However, it is a complex systems engineering. In order to truly realize the purpose of innovation and entrepreneurship education activities. It needs a number of supporting measures. In short, the student entrepreneurship education both theoretical and practical, which requires us to boldly explore, dare to practice, and constantly sum up experience in practice.

\section{References}

[1] PR Newswir. Babson College Entrepreneurship Educators Conference Unites Entrepreneurs and Educators[R]. New York: Report Information from ProQuest, 2012-9-27.

[2] Seikkula Leino J. The implementation of entrepreneurship education through curriculum reform in Finnish comprehensive schools [J]. Journal of Curriculum Studies, 2011, 43(1): 69-85.

[3] Kelley D J, Ali A, Brush C. Global Entrepreneurship Monitor United States Report 2011 [R]. Babson College Founding and Sponsoring Institution Baruch College Sponsoring Partner Institution, 2012.

[4] Donald F. Kuratko. The Emergence of Entrepreneurship Education: Development, Trends, and Challenges [J]. Entrepreneurship Theory and Practice, 2005: 1042-2587.

[5] Conlin Jones, Jack. A contemporary approach to entrepreneurship education [J]. Education and Training.2004, vol (46):416-423. 
[6] Katz J A. The chronology and intellectual trajectory of American entrepreneurship education: 1876-1999 [J]. Journal of business venturing, 2003, 18(2): 283-300. http://www.babson.edu/academics/centers/blankcenter/pages/home.aspx. 